\title{
Do the Protected Areas Network of the State of Minas Gerais Maintain Viable Populations of the Lowland Tapir (Tapirus terrestris)?
}

\author{
Anderson Aires Eduardo ${ }^{* *}$, André V. Nunes ${ }^{2} \&$ Daniel Brito ${ }^{3}$
}

\author{
${ }^{1}$ Instituto de Biologia, Universidade Federal da Bahia - UFBA, Salvador, BA, Brasil \\ ${ }^{2}$ Museu de Zoologia João Moojen, Departamento de Biologia Animal, Universidade Federal de Viçosa - UFV, Viçosa, \\ MG, Brasil \\ ${ }^{3}$ Departamento de Ecologia, Instituto de Ciências Biológicas, Universidade Federal de Goiás - UFG, Goiânia, GO, Brasil
}

\begin{abstract}
Historically, the creation of protected areas has occupied a forefront role among conservation strategies to protect wildlife. However, the effectiveness of such areas in maintaining viable populations has been a matter of debate. The present study aims to evaluate the efficiency of the protected areas network in the state of Minas Gerais, southeastern Brazil, in maintaining viable populations of Tapirus terrestris. We used the software VORTEX to model the viability of tapir populations in 65 protected areas found in the state. Our results indicate that 14 protected areas are not able to maintain lowland tapir populations in the long-term. It was also observed that 16 protected areas would suffer from genetic erosion and demographic stochasticity. Four protected areas would hold populations under the negative effects of genetic stochasticity. A total of 31 protected areas are predicted to hold viable populations. The results stress the necessity of more efficient and careful planning for resource allocation in the management of protected areas in the state of Minas Gerais, or population declines and local extinctions are expected to affect the lowland tapir in the near future.
\end{abstract}

Key words: Extinction, Population Viability Analysis, VORTEX.

\section{Introduction}

Its status as a megadiverse country implies to Brazil a great responsibility in safeguarding its biodiversity (Rylands \& Brandon 2005). The creation of protected areas is the backbone of the country strategies to achieve such goal, and the number of such sites has increased in the last decades (Mittermeier et al. 2005). The first national protected area in Brazil has part of its boundaries in the state of Minas Gerais (Itatiatia National Park, created in 1937) (Mittermeier et al. 2005). The first state protected area completely located within the state was created in 1944 (Rio Doce State Park) (Minas Gerais 1944). Nowadays, the state's protected area network comprises a total of 183 sites, covering $3.6 \%$ of the state's area (Lima et al. 2005).

There is an ongoing discussion regarding if the best conservation strategy is to expand the existing protected area network or to allocate resources outside protected

\footnotetext{
*Send correspondence to: Anderson Aires Eduardo Instituto de Biologia, Universidade Federal da Bahia - UFBA, Rua Barão de Geremoabo, 147, Campus de Ondina, CEP 40170-290, Salvador, BA, Brasil e-mail: andderson.a@hotmail.com
}

areas, improving landscape permeability (Arponen et al. 2010; Pressey et al. 2007). Despite the importance of this issue, another question remains: how efficient is the current protected areas network? If it is not performing well, what is needed to improve its effectiveness? These questions might be trickier than imagined, and several research projects addressed these issues (e.g. Brunner et al. 2001; Lima et al. 2005). In the case of the Minas Gerais network, the evaluation of effectiveness focused solely on the administrative management aspects of the protected areas (Lima et al. 2005; Alves et al. 2010; Rezende et al. 2010). To our knowledge, a species-specific biological-driven parameter of effectiveness, such as the capacity of protected areas to maintain viable populations, has not yet been used to evaluate this network.

Even though the use of modeling approaches to guide conservation actions is commonplace nowadays (Akçakaya \& Sjögren-Gulve 2000; Stein 2002; Schnase et al. 2007), evaluating the viability of large sets of species on a site is no trivial task, due to data availability and/or methodological constraints (Akçakaya \& Sjögren-Gulve 
2000; Hildenbrandt et al. 2006). In this context, as largebodied species are more prone to extinction (Schmidt \& Jensen 2003; Tilman et al. 1994), the use target species as focal organisms to conduct such analyses might be a good strategy. Therefore, the present study aims to evaluate the effectiveness of the protected areas network of the state of Minas Gerais in southeastern Brazil to maintain viable lowland tapir populations.

\section{Methods}

\section{Tapirus terrestris natural history}

The lowland tapir (Tapirus terrestris) is the only native tapir species that occur in Brazil (Wilson \& Reeder 2005). Historically, it occupied a wide range of habitat types and probably was found throughout the Brazilian territory, with the exception of the extreme southern portion of the country (Naveda et al. 2008). Currently, populations are declining across the species range (Naveda et al. 2008), and have already been extirpated in the Caatinga and severely reduced and fragmented in the Cerrado and in the Atlantic Forest (Naveda et al. 2008). A summary of the life history traits of the lowland tapir used as input to construct the viability model is given in Table 1 .

\section{Population viability analysis}

We used the software VORTEX (version 9.92) (Lacy et al. 2008 ) to model lowland tapir population viability in each protected area in the state of Minas Gerais. We only modeled strict protected areas, and did not include sustainable use or private protected areas in our analysis. Information on the existing protected areas network was obtained from national (Instituto Chico Mendes de Conservação da Biodiversidade - www.icmbio.gov.br) and state (Instituto Estadual de Florestas de Minas Gerais - www.ief.mg.gov. br) environmental agencies databases.

For each site, a total of 1000 iteractions were conducted for a period of 1000 years. The probability of extinction (PE) was computed as the proportion of iterations that had gone extinct. A population was considered as viable if it exhibits $\mathrm{PE}<0.05$ and retains heterozigosity ( $\mathrm{He}$, a surrogate for genetic diversity) $>0.90$. The initial population size was set as equal to the protected area's carrying capacity, which was calculated using the conservative density of 0.5 individuals/ $\mathrm{km}^{2}$ (Naveda et al. 2008). A summary of model parameters used as inputs in VORTEX is provided in Appendix 1.

A sensitivity analysis was conducted in order to evaluate which parameters might influence model projections (McCarthy et al. 1995). Due to the large number of populations modeled, the sensitivity analyses were conducted only for the critical lowland tapir population sizes (i.e. 50 animals for demographic stability - MVPd; and 150 animals for genetic stability - MVPg) (Médici et al. 2007). In the present study, the input parameters targeted for sensitivity analyses were: inbreeding depression, mortality rates, sex ratio, percentage of females breeding, and population density. Scenarios with $\pm 10 \%$ of the original values were created for each one of the aforementioned parameters. For inbreeding depression, we ran one scenario with, and one without the onset of such process. For the population density parameter, we constructed a scenario using a less conservative population density of 1.5 individuals $/ \mathrm{km}^{2}$. All sensitivity scenarios were statistically compared with the baseline scenario employing $t$ tests, with a significance level of $5 \%$.

\section{Results}

\section{Effectiveness of the protected areas}

Our results show that 31 out of 65 protected areas are capable of maintaining viable lowland tapir populations (Figure 1; Table 2). The model predictions show that fourteen protected areas are not able to maintain lowland tapir populations (Figure 1; Table 2). Sixteen protected areas have tapir populations that will suffer from demographic and genetic stochasticity and they will need to implement wildlife management actions to improve the likelihood of persistence for tapirs within their boundaries (Figure 1; Table 2). Four protected areas have tapir populations that are predicted to persist in the time frame analyzed, but that will suffer from genetic erosion, and will benefit if management strategies focusing on recovering genetic diversity are put into practice (Figure 1; Table 2).

\section{Sensitivity analysis}

Inbreeding depression influenced the demography of small lowland tapir populations (50 individuals), but did not exhibit influence in population genetics (Figure 2; Table 2). On other hand, for large populations (150 individuals), inbreeding depression influenced genetic diversity (Figure 2; Table 2). The mortality rate negatively affected all parameters in small populations (Figure 2; Table 2). In large populations, mortality rate affected population growth rate and population size, but probability of extinction was not sensible to changes in this parameter (Figure 3; Table 2).

The availability of breeding females has strong effects in small populations (Figure 2; Table 2), but do not affect probability of extinction or heterozigosity in large populations (Figure 3; Table 2). Large populations were sensitive for population growth rate and population size (Figure 3; Table 2). Small populations were sensible to changes in sex ratio (Figure 2; Table 2) whereas large populations were affected only in population growth rate and population size (Figure 3; Table 2). 
Table 1. Results of the simulations for lowland tapir populations in the 65 protected areas studied. Values in italics indicate viability (i.e. $P E<0.05, \mathrm{He}>0.90$; see Material and Methods). Protected areas categories: ES = Ecological Station; NP = National Park; $\mathrm{SP}=\mathrm{State}$ Park; BR = Biological Reserve; WLR = Wildlife Refuge. All these categories were defined by the national system of protected areas (Brazilian Law number 9985, of July 18, 2000).

\begin{tabular}{|c|c|c|c|c|c|c|c|}
\hline Protected area & $\mathbf{r}$ & SD & PE & $\mathbf{N}$ & SD & He & SD \\
\hline Acauã ES $S^{* * * *}$ & 0.03 & 0.06 & 0.00 & 99.28 & 7.56 & 0.91 & 0.02 \\
\hline Água Limpa ES* & 0.14 & 0.21 & 1.00 & 0.00 & 0.00 & 0.00 & 0.00 \\
\hline Arêdes ES* & 0.01 & 0.19 & 1.00 & 3.00 & 0.00 & 0.00 & 0.00 \\
\hline Cercadinho ES* & 0.00 & 0.21 & 1.00 & 0.00 & 0.00 & 0.00 & 0.00 \\
\hline Corumbá ES* & 0.00 & 0.20 & 1.00 & 0.00 & 0.00 & 0.00 & 0.00 \\
\hline Fechos ES ${ }^{* *}$ & -0.01 & 0.16 & 0.97 & 5.18 & 3.09 & 0.31 & 0.25 \\
\hline Mar de Espanha ES* & 0.02 & 0.21 & 1.00 & 0.00 & 0.00 & 0.00 & 0.00 \\
\hline Mata do Cedro ES $S^{* *}$ & 0.00 & 0.13 & 0.64 & 11.64 & 6.00 & 0.53 & 0.17 \\
\hline Mata dos Ausentes ES ${ }^{* *}$ & -0.01 & 0.17 & 0.99 & 4.86 & 2.54 & 0.29 & 0.22 \\
\hline Sagarana ES & 0.02 & 0.08 & 0.02 & 36.97 & 10.55 & 0.79 & 0.07 \\
\hline Tripuí ES** & -0.01 & 0.19 & 1.00 & 5.00 & 0.00 & 0.00 & 0.00 \\
\hline Pirapitinga $\mathrm{ES}^{* *}$ & 0.00 & 0.13 & 0.61 & 10.86 & 5.52 & 0.54 & 0.17 \\
\hline Cavernas do Peruaçu NP ${ }^{* * * *}$ & 0.04 & 0.04 & 0.00 & 1129.67 & 16.48 & 0.99 & 0.00 \\
\hline Serra da Canastra $\mathrm{NP}^{\star * * *}$ & 0.04 & 0.04 & 0.00 & 3979.17 & 56.78 & 1.00 & 0.00 \\
\hline Serra do Cipó NP**** & 0.04 & 0.04 & 0.00 & 671.18 & 11.61 & 0.98 & 0.00 \\
\hline Emas $\mathrm{NP}^{* * * *}$ & 0.03 & 0.05 & 0.00 & 196.17 & 8.15 & 0.95 & 0.01 \\
\hline Sempre-Vivas NP**** & 0.04 & 0.04 & 0.00 & 2468.34 & 31.53 & 1.00 & 0.00 \\
\hline Itatiaia NP**** & 0.04 & 0.04 & 0.00 & 594.78 & 13.07 & 0.98 & 0.00 \\
\hline Caparaó $\mathrm{NP}^{\star * * *}$ & 0.04 & 0.04 & 0.00 & 630.70 & 13.38 & 0.98 & 0.00 \\
\hline Grande Sertão Veredas NP**** & 0.04 & 0.04 & 0.00 & 2935.24 & 36.27 & 1.00 & 0.00 \\
\hline Caminho Gerais SP & -0.01 & 0.16 & 0.91 & 31.70 & 30.12 & 0.58 & 0.21 \\
\hline Campos Altos SP** & -0.01 & 0.15 & 0.87 & 7.44 & 3.57 & 0.39 & 0.22 \\
\hline Baleia SP* & 0.15 & 0.20 & 1.00 & 0.00 & 0.00 & 0.00 & 0.00 \\
\hline Mata Seca SP & 0.03 & 0.05 & 0.00 & 202.26 & 7.69 & 0.95 & 0.01 \\
\hline Serra da Candonga SP $\mathrm{SP}^{* * *}$ & 0.02 & 0.07 & 0.00 & 58.89 & 9.65 & 0.85 & 0.04 \\
\hline Serra do Brigadeiro SP $\mathrm{P}^{* * * *}$ & 0.03 & 0.04 & 0.00 & 296.66 & 7.94 & 0.97 & 0.00 \\
\hline Serra do Papagaio $\mathrm{SP}^{* * * *}$ & 0.04 & 0.04 & 0.00 & 453.89 & 10.80 & 0.98 & 0.00 \\
\hline Serra do Rola-Moça SP*** & 0.03 & 0.06 & 0.00 & 72.70 & 9.65 & 0.88 & 0.03 \\
\hline Grão Mogol SP***** & 0.04 & 0.04 & 0.00 & 661.85 & 12.12 & 0.98 & 0.00 \\
\hline Nova Baden SP* & 0.02 & 0.21 & 1.00 & 0.00 & 0.00 & 0.00 & 0.00 \\
\hline Serra Nova SP & 0.03 & 0.05 & 0.00 & 248.85 & 7.93 & 0.96 & 0.01 \\
\hline Sete Salões SP & 0.03 & 0.05 & 0.00 & 246.30 & 7.40 & 0.96 & 0.01 \\
\hline Biribiri SP $\mathrm{SP}^{\star * * *}$ & 0.03 & 0.04 & 0.00 & 335.86 & 9.33 & 0.97 & 0.00 \\
\hline Ibitipoca SP $\mathrm{P}^{\star *}$ & 0.00 & 0.11 & 0.28 & 18.62 & 8.14 & 0.65 & 0.13 \\
\hline Intendente $\mathrm{SP}^{\star *}$ & -0.01 & 0.16 & 0.86 & 26.86 & 22.49 & 0.56 & 0.21 \\
\hline Itacolomi SP & 0.03 & 0.05 & 0.00 & 147.28 & 6.79 & 0.93 & 0.01 \\
\hline Rio Corrente SP $\mathrm{P}^{* * * *}$ & 0.03 & 0.06 & 0.00 & 96.10 & 8.99 & 0.90 & 0.02 \\
\hline Rio Doce SP S $^{* * * *}$ & 0.04 & 0.04 & 0.00 & 713.99 & 14.15 & 0.99 & 0.00 \\
\hline Rio preto $\mathrm{SP}^{* * * *}$ & 0.03 & 0.05 & 0.00 & 210.90 & 8.38 & 0.95 & 0.01 \\
\hline Verde Grande SP**** & 0.04 & 0.04 & 0.00 & 506.29 & 11.09 & 0.98 & 0.00 \\
\hline Veredas do Peruaçu SP**** & 0.04 & 0.04 & 0.00 & 608.53 & 12.59 & 0.98 & 0.00 \\
\hline Lagoa do Cajueiro SP & 0.04 & 0.04 & 0.00 & 406.13 & 9.33 & 0.97 & 0.00 \\
\hline Lapa Grande SP** & -0.01 & 0.16 & 0.91 & 15.49 & 10.52 & 0.50 & 0.23 \\
\hline Montezuma SP* & 0.00 & 0.18 & 1.00 & 0.00 & 0.00 & 0.00 & 0.00 \\
\hline Pau Furado SP** & -0.01 & 0.18 & 0.99 & 5.75 & 1.50 & 0.37 & 0.25 \\
\hline Pico do Itambé SP & 0.03 & 0.06 & 0.00 & 89.34 & 8.11 & 0.90 & 0.02 \\
\hline Serra da Boa Esperança SP** & -0.01 & 0.16 & 0.91 & 12.75 & 8.23 & 0.53 & 0.19 \\
\hline Serra das Araras SP $\mathrm{P}^{\star * * *}$ & 0.03 & 0.05 & 0.00 & 219.16 & 7.85 & 0.95 & 0.01 \\
\hline
\end{tabular}

\footnotetext{
${ }^{*}$ Non-viable; ${ }^{* *}$ Subject to strong genetic and demographic stochasticity; ${ }^{* * *}$ Subject to genetic stochasticity; ${ }^{* * *}$ Viable population.
} 
Table 1. Continued...

\begin{tabular}{|c|c|c|c|c|c|c|c|}
\hline Protected area & $\mathbf{r}$ & SD & PE & $\mathbf{N}$ & SD & $\mathrm{He}$ & SD \\
\hline PE Serra do Cabral SP ${ }^{\star *}$ & -0.01 & 0.16 & 0.88 & 36.93 & 35.87 & 0.58 & 0.20 \\
\hline Serra Negra SP $\mathrm{SP}^{\star * * *}$ & 0.04 & 0.04 & 0.00 & 659.92 & 13.91 & 0.98 & 0.00 \\
\hline Serra Verde $\mathrm{SP}^{\star}$ & 0.04 & 0.17 & 1.00 & 0.00 & 0.00 & 0.00 & 0.00 \\
\hline Sumidouro $\mathrm{SP}^{*}$ & -0.01 & 0.19 & 1.00 & 0.00 & 0.00 & 0.00 & 0.00 \\
\hline Serra Azul BR ${ }^{* * * *}$ & 0.03 & 0.05 & 0.00 & 141.51 & 7.06 & 0.93 & 0.01 \\
\hline Carmo da Mata BR* & 0.15 & 0.20 & 1.00 & 0.00 & 0.00 & 0.00 & 0.00 \\
\hline Colônia 31 de Março BR ${ }^{* * * *}$ & 0.03 & 0.06 & 0.00 & 96.02 & 8.39 & 0.90 & 0.02 \\
\hline Mata Escura BR ${ }^{* * * *}$ & 0.04 & 0.04 & 0.00 & 1011.47 & 17.70 & 0.99 & 0.00 \\
\hline Fazenda Cascata BR* & 0.15 & 0.20 & 1.00 & 0.00 & 0.00 & 0.00 & 0.00 \\
\hline Fazenda São Mateus BR ${ }^{\star *}$ & -0.01 & 0.19 & 1.00 & 4.00 & 0.00 & 0.00 & 0.00 \\
\hline Jaíba $\mathrm{BR}^{\star * * *}$ & 0.03 & 0.05 & 0.00 & 122.81 & 7.69 & 0.92 & 0.02 \\
\hline Lapinha $\mathrm{BR}^{*}$ & -0.01 & 0.19 & 1.00 & 0.00 & 0.00 & 0.00 & 0.00 \\
\hline Santa Rita BR ${ }^{\star *}$ & -0.01 & 0.17 & 0.97 & 5.62 & 2.53 & 0.48 & 0.24 \\
\hline São Sebastião do Paraíso BR* & 0.02 & 0.21 & 1.00 & 0.00 & 0.00 & 0.00 & 0.00 \\
\hline Libélulas da Serra São José WLR** & -0.01 & 0.17 & 0.97 & 6.00 & 3.76 & 0.39 & 0.22 \\
\hline Mata dos Muriquis WLR ${ }^{\star * *}$ & 0.02 & 0.07 & 0.01 & 45.48 & 9.99 & 0.82 & 0.06 \\
\hline Rio Pandeiros WLR R $^{* * * *}$ & 0.04 & 0.04 & 0.00 & 1213.49 & 20.94 & 0.99 & 0.00 \\
\hline
\end{tabular}

${ }^{*}$ Non-viable; ${ }^{* *}$ Subject to strong genetic and demographic stochasticity; ${ }^{* * *}$ Subject to genetic stochasticity; ${ }^{* * * *}$ Viable population.

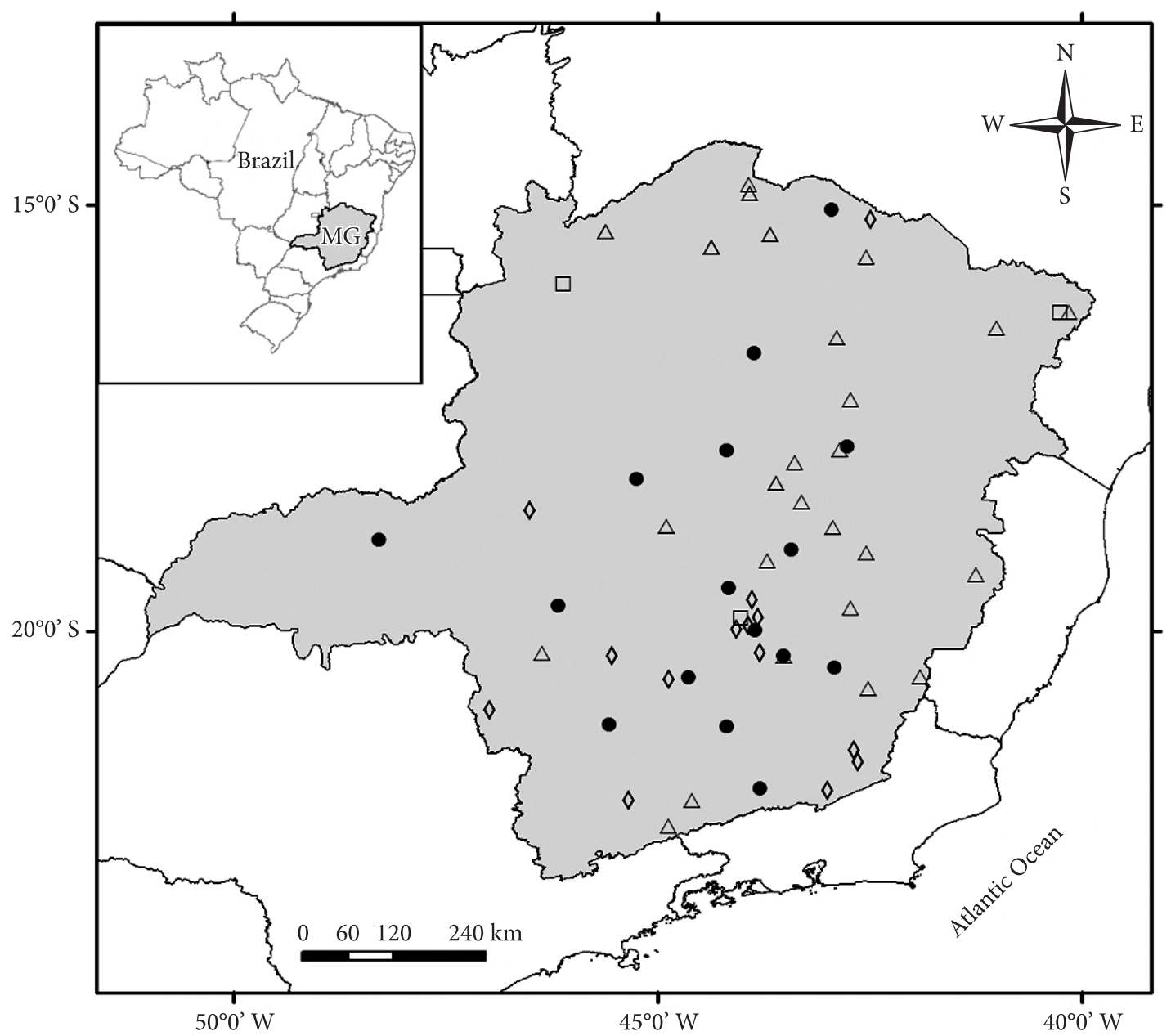

Figure 1. Map of the state of Minas Gerais, depicting the 65 protected areas investigated in the present study. $\diamond=$ non-viable populations; $\boldsymbol{0}$ = populations suffering from demographic and genetic stochasticity; $\square$ = populations suffering from genetic stochasticity; $\Delta=$ viable populations. 
Table 2. Results of the sensitivity analysis for critical population sizes simulations of lowland tapir, Tapirus terrestris. The scenarios evaluated the impacts of $\pm 10 \%$ change in input parameter values (in scenarios for mortality, breeding females available and sex ratio at birth), with or without occurrence (in the scenario for inbreeding depression) and increase (in the scenario for population density).

\begin{tabular}{|c|c|c|c|c|c|c|c|c|}
\hline Scenario & $\mathbf{r}$ & SD & PE & SD & $\mathbf{N}$ & SD & $\mathrm{He}$ & SD \\
\hline \multicolumn{9}{|c|}{ Small population (50 individuals) } \\
\hline Baseline scenario & 0.018 & 0.077 & 0.018 & 0.0059 & 40.97 & 10.37 & 0.804 & 0.063 \\
\hline No inbreeding depression & $0.029^{*}$ & 0.073 & $0.004^{*}$ & 0.0028 & $46.51^{*}$ & 5.75 & $0.798^{\mathrm{ns}}$ & 0.064 \\
\hline Mortality $-10 \%$ & $0.032^{*}$ & 0.070 & $0.002^{*}$ & 0.0020 & $46.07^{*}$ & 6.32 & $0.811^{\star}$ & 0.055 \\
\hline Mortality $+10 \%$ & $0.002^{*}$ & 0.091 & $0.110^{*}$ & 0.0140 & $29.82^{*}$ & 14.26 & $0.767^{*}$ & 0.098 \\
\hline Breeding females $-10 \%$ & $0.007^{*}$ & 0.083 & $0.050^{*}$ & 0.0097 & $34.01^{\star}$ & 13.42 & $0.776^{*}$ & 0.093 \\
\hline Breeding females $+10 \%$ & $0.026^{*}$ & 0.074 & $0.006^{*}$ & 0.0035 & $44.03^{*}$ & 8.52 & $0.807^{\text {ns }}$ & 0.060 \\
\hline Sex ratio $-10 \%$ & $0.023^{\mathrm{ns}}$ & 0.073 & $0.000^{\mathrm{ns}}$ & 0.0000 & $43.39^{*}$ & 8.96 & $0.806^{\mathrm{ns}}$ & 0.065 \\
\hline Sex ratio $+10 \%$ & $0.008^{*}$ & 0.082 & $0.058^{*}$ & 0.0105 & $34.61^{*}$ & 13.77 & $0.779^{*}$ & 0.089 \\
\hline Density 1.5 & $0.028^{\mathrm{ns}}$ & 0.058 & $0.000^{*}$ & 0.000 & $95.77^{\star}$ & 6.57 & $0.900^{*}$ & 0.022 \\
\hline \multicolumn{9}{|c|}{ Large populations (150 individuals) } \\
\hline Baseline scenario & 0.031 & 0.051 & 0.000 & 0.000 & 146.42 & 6.94 & 0.932 & 0.013 \\
\hline No inbreeding depression & $0.035^{\mathrm{ns}}$ & 0.051 & $0.000^{\mathrm{ns}}$ & 0.000 & $147.69^{*}$ & 5.29 & $0.931^{*}$ & 0.013 \\
\hline Mortality $-10 \%$ & $0.044^{*}$ & 0.048 & $0.000^{\mathrm{ns}}$ & 0.000 & $148.29^{\star}$ & 4.65 & $0.933^{\text {ns }}$ & 0.013 \\
\hline Mortality $+10 \%$ & $0.017^{\star}$ & 0.056 & $0.000^{\mathrm{ns}}$ & 0.000 & $136.63^{*}$ & 18.87 & $0.929^{*}$ & 0.013 \\
\hline Breeding females $-10 \%$ & $0.021^{*}$ & 0.021 & $0.000^{\mathrm{ns}}$ & 0.000 & $141.41^{\star}$ & 12.61 & $0.934^{\mathrm{ns}}$ & 0.011 \\
\hline Breeding females $+10 \%$ & $0.040^{*}$ & 0.040 & $0.000^{\mathrm{ns}}$ & 0.000 & $147.64^{\star}$ & 5.50 & $0.931^{\mathrm{ns}}$ & 0.013 \\
\hline Sex ratio $-10 \%$ & $0.039^{*}$ & 0.039 & $0.000^{\mathrm{ns}}$ & 0.000 & $147.76^{\star}$ & 5.23 & $0.931^{\mathrm{ns}}$ & 0.013 \\
\hline Sex ratio $+10 \%$ & $0.021^{\star}$ & 0.021 & $0.000^{\mathrm{ns}}$ & 0.000 & $142.60^{*}$ & 11.18 & $0.933^{\text {ns }}$ & 0.013 \\
\hline Density 1.5 & $0.034^{\mathrm{ns}}$ & 0.034 & $0.000^{\mathrm{ns}}$ & 0.000 & $296.24^{*}$ & 8.31 & $0.966^{*}$ & 0.004 \\
\hline
\end{tabular}

*Scenarios statistically significant at $\alpha=0.05$.
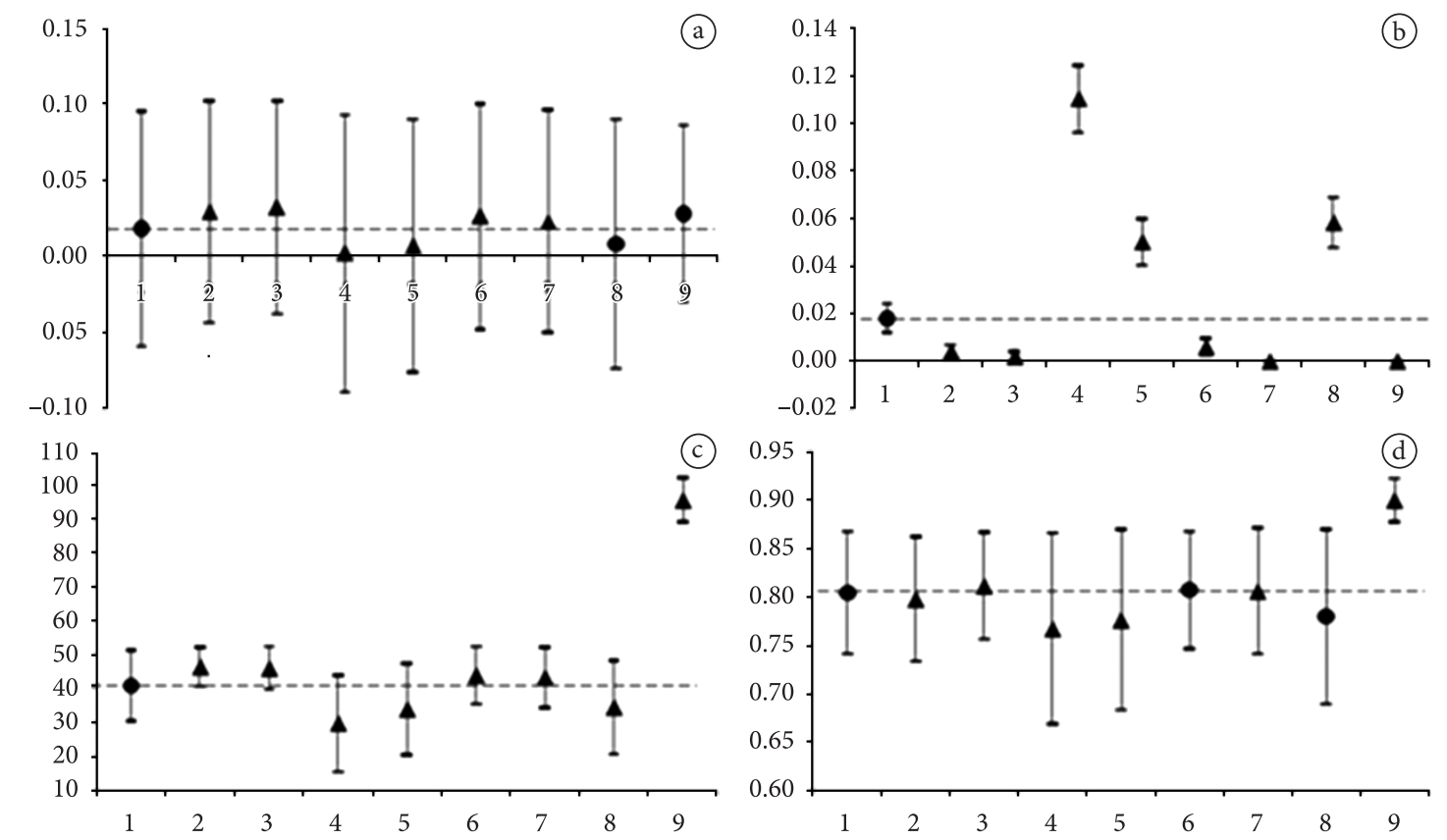

Figure 2. Results of the sensitivity analysis for small populations (50 individuals). The A, B, C and D graphs depict the effects in $r$, $P E, N$ and $H e$, respectively. In $X$ axe are the sensitivity scenarios: $1=$ baseline scenario; $2=$ non-inbred; $3=-10 \%$ mortality; $4=+10 \%$ mortality; $5=-10 \%$ breeding females; $6=+10 \%$ breeding females; $7=-10 \%$ sex ratio; $8=+10 \%$ sex ratio; $9=1.5$ individuals $/ \mathrm{km}^{2}$ density. The symbol represents statistically non-significant scenarios (i.e. p $>0.05$ ) in relation to baseline scenarios, and the represents the significant ones (i.e. $\mathrm{p}<0.05$ ) (see "model, scenarios and simulations" in Methods). The vertical bars represent one Standard Deviation. The dotted line is the reference for baseline scenario. 

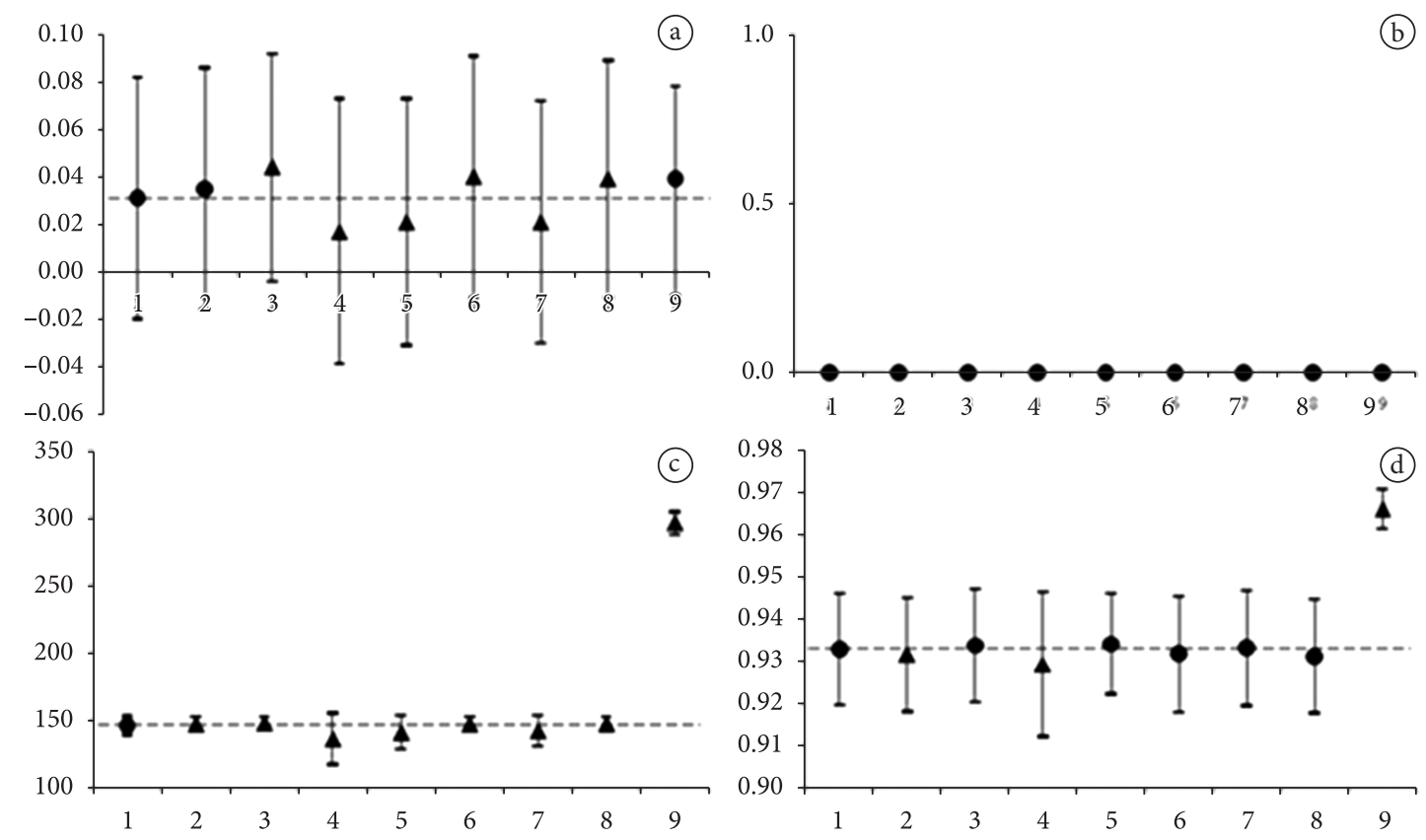

Figure 3. Results of the sensitivity analysis for large populations ( 150 individuals). The A, B, C and D graphs depicts the effects in $r$, $P E, N$ and $H e$, respectively. In $X$ axe are the sensitivity scenarios: $1=$ baseline scenario; $2=$ non-inbred; $3=-10 \%$ mortality; $4=+10 \%$ mortality; $5=-10 \%$ breeding females; $6=+10 \%$ breeding females; $7=-10 \%$ sex ratio; $8=+10 \%$ sex ratio; $9=1.5$ individuals $/ \mathrm{km}^{2}$ density. The symbol - represents statistically non-significant scenarios (i.e. p $>0.05$ ) in relation to baseline scenarios, and the $\mathbf{A}$ represents the significant ones (i.e. $\mathrm{p}<0.05$ ) (see "model, scenarios and simulations" in Methods). The vertical bars represent one Standard Deviation. The dotted line is the reference for baseline scenario.

\section{Discussion}

One of the main roles of protected areas is to maintain viable populations of species in the long-run (Bruner et al. 2001; Lima et al. 2005). However, recent attempts to evaluate effectiveness of such networks for some mammal species in Brazil produced results that might raise concern (e.g. Brito \& Grelle 2004; Brito et al. 2008), with only a small percentage of protected areas being capable to hold viable populations. In the state of Minas Gerais, two protected areas (Caparaó National Park and Rio Doce State Park) are predicted to house viable populations for two threatened species: the lowland tapir (Tapirus terrestris) (this study) and the northern muriqui (Brachyteles hypoxanthus) (Brito et al. 2008). These two protected areas could be considered as of paramount importance for the conservation of large mammal diversity in the state. Unfortunately, management interventions, which consume both economic and human resources, are urgently needed to avoid local extinctions and population declines throughout the state in the near future.

We did not account for habitat heterogeneity in our modelling approach. This consideration is relevant, especially within the state of Minas Gerais which overlaps with three of the Brazilian biomes (Cerrado, Caatinga and Atlantic Forest) (Drummond et al. 2009). We also did not consider human-driven threats, such as hunting, in our models. However, the lowland tapir suffers from hunting throughout its distribution (Naveda et al. 2008), and our sensitivity analysis results show that changes in mortality rate might affect persistence of populations.
Large mammals play key roles in ecosystems, such as seed dispersal, trampling, regulation of prey/predator populations (Boddicker et al. 2002; Stoner et al. 2007). They require large areas to maintain viable populations (Traill et al. 2007). If protected areas network do not incorporate the area requirements of large mammals, such species might be lost in the long-run, as the ecological processes they took part in. Chiarello (2000) had already shown that well-structured mammal communities can only occur in large areas. A possible short-term strategy to be used as an urgent measure is the creation of buffer zones, particularly around small-isolated protected areas. In this sense, an efficient protected areas network will need to be managed as a network, and not as a group of independent sites. Also, management actions outside protected areas, considering that such areas are inserted into a mosaic landscape with several land uses, must be taking into account (Pressey et al. 2007).

Another way of evaluating the effectiveness of protected areas is through their administration. Lima et al. (2005) verified that in the state of Minas Gerais, $87 \%$ of such areas do not have a management plan, the most basic document of a protected area according to the Brazilian protected area legislation. Additionally, more than $60 \%$ are "paper parks", they legally exist, but lack even the minimum infrastructure for operating adequately (Lima et al. 2005). In this scenario, it is not a surprise that the majority of the protected areas are not able to maintain viable populations.

The present study is concentrated in national and state protected areas in the state of Minas Gerais. Even though 
they are not the only ones (private and municipal protected areas exist), they are considered the backbone areas to biodiversity conservation in the state of Minas Gerais. Even if these protected areas have not been created specifically for maintaining viable populations of the lowland tapir, it is expected that they should do it.

\section{Acknowledgements}

We thank the anonymous reviewers who contributed greatly to improve the manuscript. Daniel Brito's research is supported by CNPq (project \# 305631/2009-8).

\section{References}

Akçakaya HR \& Sjögren-Gulve P. 2000. Population viability analyses in conservation planning: an overview. Ecological Bulletins, 48:9-21.

Alves RG et al., 2010. Análise da gestão das unidades de conservação do sistema estadual de áreas protegidas de Minas Gerais. Espaço e Geografia, 13:1-35.

Arponen A et al., 2010. Costs of integrating economics and conservation planning. Conservation Biology, 24:1198-1204. PMid:20575989. http://dx.doi. org/10.1111/j.1523-1739.2010.01539.x

Boddicker M, Rodriguez JJ \& Amanzo J, 2002. Indices for assessment and monitoring of large mammals within an adaptive management framework. Environment Monitoring and Assessment, 76:105-123. PMid:12125745. http://dx.doi. org/10.1023/A:1015225022101

Brito D \& Grelle CEV, 2004. Effectiveness of a reserve network for the conservation of the endemic marsupial Micoureus travassosi in Atlantic Forest remnants in southeastern Brazil. Biodiversity and Conservation, 13:2519-2536. http://dx.doi. org/10.1023/B:BIOC.0000048450.85086.00

Brito D, Grelle CEV \& Boubli JP, 2008. Is the Atlantic Forest protected area efficient in maintaining viable populations of Brachyteles hypoxanthus? Biodiversity \& Conservation, 17:3255-3268. http://dx.doi.org/10.1007/s10531-008-9427-z

Bruner AG et al., 2001. Effectiveness of parks in protecting tropical biodiversity. Science, 291:125-128. PMid:11141563. http://dx.doi.org/10.1126/science.291.5501.125

Chiarello AG, 2000. Density and population size of mammals in remnants of Brazilian Atlantic Forest. Conservation Biology, 14:1649-1657. http://dx.doi. org/10.1046/j.1523-1739.2000.99071.x

Drummond GM et al., 2009. Biota Minas: diagnóstico do estado do conhecimento sobre a biodiversidade do Estado de Minas Gerais. Belo Horizonte: Fundação Biodiversitas.

Hildenbrandt H, Müller MS \& Grimm V, 2006. How to detect and visualize extinction thresholds for structured PVA models. Ecological Modelling, 191:545-550. http://dx.doi. org/10.1016/j.ecolmodel.2005.05.016
Lacy RC, Borbat M \& Pollak JP, 2008. VORTEX: A stochastic simulation of the extinction process. version 9.92. Brookfield: Chicago Zoological Society.

Lima SG, Ribeiro GA \& Gonçalves W, 2005. Avaliação da efetividade de manejo das unidades de conservação de proteção integral em Minas Gerais. Revista Árvore, 29:647-653.

McCarthy MA, Burgman MA \& Ferson S. 1995. Sensitivity analysis for models of population viability. Conservation Biology, 73:93-100.

Médici EP et al., 2007. Workshop para a Conservação da Anta Brasileira: Relatório Final. Sorocaba: IUCN/SSC Tapir Specialist Group - TSG \& IUCN/SSC Conservation Breeding Specialist Group CBSG.

Minas Gerais (Estado), 1944. Decreto-lei no 1119, de 14 de julho de 1944. In: Instituto Estadual de Florestas - IEF. Parque Estadual do Rio Doce. IEF. Available from: <http://www. ief.mg.gov.br/images/stories/riodoce/decreto1119.pdf>.

Mittermeier RA et al., 2005. Uma breve história da conservação da biodiversidade no Brasil. Megadiversidade, 1:14-20.

Naveda A et al., 2008. Tapirus terrestris. In: International Union for Conservation of Nature - IUCN. IUCN Red List of Threatened Species. IUCN. Available from: <http:// www.iucnredlist.org $>$.

Pressey $\mathrm{R}$ et al., 2007. Conservation planning in a changing world. Trends in Ecology \& Evolution, 22:583-592. http:// dx.doi.org/10.1016/j.tree.2007.10.001

Rezende JLP et al., 2010. Avaliação da gestão das UC do Sistema Estadual de Áreas Protegidas de Minas Gerais. Revista Geografias, 06:87-106.

Rylands AB \& Brandon K, 2005. Unidades de conservação brasileiras. Megadiversidade, 1:27-35.

Schmidt, NM \& Jensen PM, 2003. Changes in mammalian body length over 175 years - Adaptations to a fragmented landscape? Conservation Ecology, 7:1-6.

Schnase J, Cushing J \& Smith J, 2007. Biodiversity and ecosystem informatics. Journal of Intelligent Information Systems, 29:1-6. http://dx.doi.org/10.1007/s10844-006-0027-7

Stoner KE et al., 2007. The role of mammals in creating and modifying seedshadow in tropical forests and some possible consequences of their elimination. Biotropica, 39:316-327. http://dx.doi.org/10.1111/j.1744-7429.2007.00292.x

Stein L, 2002. Creating a bioinformatics nation. Nature, 417:119120. PMid:12000935. http://dx.doi.org/10.1038/417119a

Tilman D et al., 1994. Habitat destruction and the extinction debt. Nature, 371:65-66. http://dx.doi.org/10.1038/371065a0

Traill LW, Bradshaw CJA \& Brook BW, 2007. Minimum viable population size: A meta-analysis of 30 years of published estimates. Biological Conservation, 139:159-166. http:// dx.doi.org/10.1016/j.biocon.2007.06.011

Wilson DE \& Reeder DM, 2005. Mammal Species of the World: a taxonomic and geographic. Washington: Smithsonian Institute Press. 